\title{
NEWS
}

\section{Flu in wild birds sparks fears of mutating virus}

T he deaths in China of more than 1,000 migratory birds from the flu strain $\mathrm{H} 5 \mathrm{~N} 1$

has left experts struggling to square the outbreak with their knowledge of the virus. At the same time, rumours are beginning to circulate that humans in the region have also fallen victim to the disease - although official sources have so far denied this.

The H5N1 strain has killed at least 53 people in Asia since late 2003, and is seen as one of the prime candidates for sparking a human pandemic. Migratory birds can act as carriers of flu, but their role in spreading highly dangerous strains such as $\mathrm{H} 5 \mathrm{~N} 1$ remains a matter for debate.

Until the latest outbreak, only a handful of migratory birds were known to have died from H5N1. This led some experts to suggest that the migrants are asymptomatic carriers of the virus, causing the occasional outbreak among poultry populations along their migration routes. Others believed that the small number of deaths among migrants were simply the result of wild birds picking up the infection from local ducks or chickens.

But the revelation on 21 May that at least 500 wild birds across five different species had died from the virus has dramatically altered the situation. With H5N1 now seeming to be highly infectious and lethal among the migrants, experts fear that the virus's genes may have mutated or reassorted.

To find out, the World Health Organization (WHO) is pressuring China to release samples for sequencing and analysis. ${ }^{\alpha}$ This is an

\section{IMAGE \\ UNAVAILABLE FOR COPYRIGHT REASONS}

Health workers disinfect anarea in Qinghai. exceptional case," says Maria Cheng, the WHO's spokeswoman in Beijing. "We want to see the virus as soon as we can."

China had not reported any cases of H5N1 in people or birds since a previous poultry outbreakended in June 2004. But several Internet sites including ProMED-mail, an online database of health-related news, are now reporting that people are dying as a result of the latest outbreak (see 'China rejects Internet claims of human cases', below). Some sources are claiming there have been up to 120 fatalities.

The Chinese health authorities deny that any human cases have been found. Since early May, when 178 suspicious waterfowl deaths were first reported in the Niannaisuoma village of northeastern Qinghai, authorities have quarantined the area, requiring people going there to wear goggles, masks and gowns. Increased surveillance so far has found no sick people, officials say.

There is no evidence of human to human transmission in the area, and large-scale transmission from so few wild birds directly to humans is unlikely, says virologist Vincent Deubel, who heads the Pasteur Institute in Shanghai. "A more virulent form for birds does not mean a more virulent form for humans," he explains. "It would be unrealistic to expect so many human deaths from an outbreak in only 500 birds. $^{.}$

But the numbers of reported bird deaths might hugely underestimate the actual toll, says Fusheng Guo, coordinator for the UN Food and Agriculture Organization's regional avian-
Reports that the outbreak of avian flu among wild birds in Qinghai has resulted in any human cases of the disease are being denied by China.

Rumours that people had been infected began on 25 May, when the ProMED-mail Internet alert system relayed a translation of an article from the independent Chinese website Boxun News, which is based in the United States. ProMED warned that the information was unofficial and needed to beconfirmed.

It was an article on Boxun News that firstled ProMED toreport the outbreak of severe acute respiratory syndrome (SARS) in 2003. Until then, China had been able to cover up the presence of

\section{IMAGE UNAVAILABLE FOR COPYRIGHT REASONS}

In a flap: a sudden outbreak of H5N1 fluin migratory birds has caught experts unaware.

flu surveillance network. "Many of them won't be found," he says, adding that his colleagues in Qinghai are reporting many more deaths every day. “'I'm very worried about this." In fact, less than a week after the figure of 519 bird deaths was released, jia Youling, director of the veterinary bureau at Chinas agriculture ministry, revised the number to more than 1,000 .

Baoxu Huang, director of Chinas National

\section{China rejects Internet claims of human cases}

the disease. This time, the initial Boxun report claimed six people had died of avian flu in Qinghai in May. As Nature went to press, Boxun was reporting asmany as 200 cases and 121 dead, and detailing the locations.

The reports were swiftly rebuked on 26 May by Xinhua, the Chinese official press agency. which denied that any human cases had occurred. But the statement added that "hospitals in Gangca County, where the avian flu cases were reported, have opened up a separate outpatient department for feverish patients".

A spokesman for the World Health Organization $(\mathrm{WHO})$ says that the agency has 


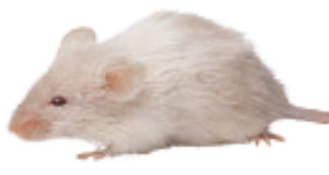

P.ASTIC PERIL

Mousestudy suggests bisphenol A could

raise risk of breast cancer.

unw.nat ure.com/news

\section{UK research councils claim success for open-access publishing plan}

\section{LONDON}

Britain's main public funders for research seem to have achieved the impossible they've come up with a policy that pleases both sides in the debate over open-access publishing. But appearances can be deceptive. Behind public praise for the statement, some publishers are voicing fears that small journals will go out of business, which could put scientific societies at risk.

Opponents of the current system of scientific publishing have lobbied hard in recent years, calling for all publicly funded research to be made available in free-toaccess journals or archives. Their campaign, which in the United States included television adverts, has worried academic publishers. The fear is that libraries will cancel their subscriptions if papers are made available for free.

Supporters of open access are claiming victory in the wake of rules drawn up by Britain's research councils, which distribute most government science funding. The policy has delighted them because it requires all council-funded papers be put in an open-access archive "as soon as possible" after publication. Other major funders of research around the globe, including the US National Institutes of Health (NIH), allow researchers to wait up to a year before depositing their work.

Stevan Harnad, an advocate of open access and a cognitive scientist at the University of Southampton, believes that the UK policy's insistence on submission will make the use of open-access archives a regular part of academic life. "Once the history of this is written, this statement will be the single most important factor," he says.

But a crucial change to the policy, made following complaints from publishers, could dilute the power of archives. After consulting on an initial draft issued last autumn, the councils changed the policy so that submissions to archives will be subject to the copyright andlicensing arrangement of the journal publishing the paper. Publishing executives say privately that they can now rewrite their rules so that submission takes place after a delay of several months, which will

\section{The UK policy}

Scientists will submitpapers to subjectspecific archives or to an equivalentrun by their institution. The paper would only be the final text document accepted for publication, not the formatted version that is printed.

If this causes a range of archives to proliferate, access to papers should still be straightforward. Scholarly search engines, such as that unveiled las tyear by Google, automatically look through institutional repositories, so users shouldn'tneed to know where an article is actually held.

protect their subscription revenues.

Commercial journals are happy with the policy, but other publishers remain fearful. Learned societies, for example, often fund activities such as fellowship schemes through publishing. They say that libraries are strapped for cash and will consider cancelling subscriptions once archives take off, especially for journals that publish only a few times a year.

"We simply don't know how much damage this will do," says Sally Morris, chief executive of the Association of Learned and Professional Society Publishers, based in West Sussex. "If other funders follow this route, much material will be made available for free. Why would you pay?"

Harnad says there is no need to worry, as fields in which archiving is common, such as computer science and physics, show no evidence of failing journals.

The Wellcome Trust, Britain's biggest medical charity, is even more bullish about the idea. It said on 19 May that all papers produced using its money will have to be submitted to the NIH archive PubMed Central or to the British equivalent that is being developed. "Old journals sometimes cease to publish, but new ones spring up," says Mark Walport, the trust's director. "I have some sympathy with the learned societies, but it is not the primary mission of funders to support them."

The councils' statement still has to be "fine-tuned", say officials. Originallydue for release this month, it has been put back until the summer, but is not expected to undergo significant changes before then. Jim Giles 